Asian-Australasian Journal of

Food Safety and Security

ISSN 2523-1073 (Print) 2523-2983(Online)

www.ebupress.com/journal/aajfss

\title{
Article \\ Effectiveness of integrated nutrient management on growth and yield parameters of okra (Abelmoschus esculentus L.)
}

\author{
Masud Rana ${ }^{1}$, Md. Morshedul Islam ${ }^{1,2^{*}}$ and Md. Atiqur Rahman Bhuiyan ${ }^{1}$ \\ ${ }^{1}$ Department of Agriculture, Faculty of Science, Noakhali Science and Technology University, Noakhali-3814, \\ Bangladesh \\ ${ }^{2}$ Department of Plant Pathology, Faculty of Agriculture, Bangladesh Agricultural University, Mymensingh- \\ 2202, Bangladesh
}

*Corresponding author: Md. Morshedul Islam, Department of Plant Pathology, Faculty of Agriculture, Bangladesh Agricultural University, Mymensingh-2202, Bangladesh. Phone: +8801751003150; E-mail: morshedkhan2103@gmail.com

Received: 04 October 2020/Accepted: 23 November 2020/ Published: 30 November 2020

\begin{abstract}
Integrated use of organic and inorganic fertilizers could improve both growth and yield of okra plant. The present study was carried out to evaluate the effect of organic and inorganic fertilizer on growth and yield parameters of okra (Abelmoschus esculentus L.) at experimental area of Noakhali Science and Technology University, Bangladesh during the period of $18^{\text {th }}$ December, 2018 to $19^{\text {th }}$ March, 2019 (Rabi season). In this experiment, "Arka Anamika" variety of okra was used. The experiment was laid out in Randomized Complete Block Design (RCBD) with four treatments viz. T1 = INM (organic and inorganic), T2= Inorganic (NPK), T3= Organic (cowdung), T4= Control and three replications. Data were taken on the growth and yield parameters such as plant height $(\mathrm{cm})$, number of leaves per plant, number of branches per plant, days to first flowering (days), number of fruit per plant, individual fruit weight $(\mathrm{gm})$, fruit length $(\mathrm{cm})$ and fruit diameter $(\mathrm{cm})$. Among all treatments INM (organic and inorganic) was responsible for highest plant height $(49.96 \mathrm{~cm}$ ), maximum number of leaves per plant (22.33) and branches per plant (6.33), accelerated days to first flowering (39 days), increases the number of fruit per plant (14.33), individual fruit weight $(24.89 \mathrm{gm})$, fruit length $(15.5 \mathrm{~cm})$ and fruit diameter $(1.98 \mathrm{~cm}$ ). So this study clearly indicated that, among all treatments INM (Organic and inorganic) performed the best and it will be suitable for okra production.
\end{abstract}

Keywords: okra; inorganic fertilizer; organic fertilizer; growth; yield

\section{Introduction}

Okra is one of the most popular vegetable crops grown throughout the tropics of the world during spring, summer and kharif seasons. It is a vegetable crop that belongs to the genus Abelmoschus, family Malvaceae and it has two main species such as Abelmoschus esculentus and Abelmoschus caillei (Siemonsma, 1982). It probably originated in Ethiopia and is widely spread all over tropical, subtropical and warm temperate regions of the world (Benchasri, 2012). The vegetables of okra is mainly grown for its young immature fruits and consumed as a vegetable, raw, cooked or fried (Molik et al., 2016). It is a very good source of dietary fiber, magnesium, manganese, potassium, vitamin K, vitamin C, folate, B1, and B6 (Badrie, 2016). Okra is said to be of economic importance because of its nutritional value that has the potential to improve food security (FAO, 2006). In Bangladesh, vegetable production is not uniform round the year, maximum in winter but less in summer. Around 30\% of total vegetables are produced during summer and 70\% in winter (Hossain, 1992). The present consumption of vegetables in Bangladesh is $112 \mathrm{gm} /$ day/capita (23 gm leafy vegetables, $89 \mathrm{gm}$ nonleafy vegetables), which is far below the minimum average requirement of $400 \mathrm{gm} /$ day/capita (FAO/WHO, 
2003). Therefore, there is a big gap between the requirement and the supply of vegetables in Bangladesh. Successful okra production may contribute partially in solving vegetable scarcity in summer (Chowdhury et al., 2014). Okra production in the country is low compared to other countries. Total production of okra was about 240 thousand tons from 7287.5 ha in 2009 and the average yield was about 3.38 t/ha (BBS, 2010). The requirements of fertilizers in okra are important for the early vegetative growth and total production of yield. Integrated use of organic and inorganic fertilizers can improve crop productivity (Mal et al., 2013) and enhances soil nutrient status. Soil fertility is usually maintained by the application of organic and inorganic fertilizers and there is also an improvement in the physical and biological properties of the soil (Atijegbe, 2014) which increases yield of okra. Organic and inorganic fertilizers furnishes large portion of macro and micro nutrients in soil and which are specific in function and must be supplied to plants at the right time and at the right quantity. Lack of sufficient amounts of these nutrients result in poor performance of the okra with growth been affected resulting to low yield (Chauhan, 1972). Therefore, this research investigated to find out the response of okra to organic and inorganic fertilization and to identify the possible fertilizer treatment which enhances both growth and yield of okra.

\section{Materials and Methods}

\subsection{Experimental site}

The study was carried out during the period of $18^{\text {th }}$ December, 2018 to $19^{\text {th }}$ March, 2019 (Rabi season) at research field of Agriculture department, Noakhali Science and Technology University, Bangladesh. The climate of the experimental area has subtropical and it has significant rainfall in most months, with a short dry season. Mechanical analysis of soil indicated that soil of experimental plot was sandy loam. The chemical analysis revealed that soil has $\mathrm{pH}$ 7.5-8.3 and slightly saline.

\subsection{Experimental material and design}

In this experiment, "Arka Anamika" variety was used as the test crop and the experiment was laid out in Randomized Complete Block Design (RCBD) and four treatments with three replications.

\subsection{Experimental treatment}

In this experiment four treatments were considered:

- $\quad \mathrm{T} 1=\mathrm{INM}\left(\right.$ Organic + Inorganic fertilizer): Cowdung $(5 \mathrm{t} / \mathrm{ha})+$ Recommended dose of NPK ha ${ }^{-1}(40 \mathrm{~kg}$ : $50 \mathrm{~kg}: 30 \mathrm{~kg}$ )

- $\mathrm{T}_{2}=$ Inorganic fertilizer: Recommended dose of NPK ha ${ }^{-1}(40 \mathrm{~kg}: 50 \mathrm{~kg}: 30 \mathrm{~kg})$

- $\mathrm{T}_{3}=$ Organic fertilizer: Cowdung (10 t/ha)

- $\mathrm{T} 4=$ Control (no fertilizer are used)

\subsection{Land preparation}

The land was prepared to fine tilth by repeated ploughing and harrowing. Cowdung and all fertilizers except urea were applied during final land preparation. Seed sowing was done on $20^{\text {th }}$ December, 2018 in the plots and maintaining the distance of $(35 \times 15) \mathrm{cm}$. Before sowing, seed treatment was done with Furadan @ 5gm. Intercultural operations was done properly when required.

\subsection{Data collection}

Data on the following parameters were recorded from the experimental plot. The height of each plant was measured $(\mathrm{cm})$ from the base of the plant to the apex with a tape measure. Height of the okra plants were recorded at 30, 45 and 60 days after sowing. Randomly selected branches of okra plants were used for the measurement of leaves number per plant at 30,45, and 60 days after sowing. The number of branches per plant was recorded at 30, 45 and 60 days after sowing. Number of days from sowing to first flower opening was recorded as days to first flowering (days). The number of fruits per plant was recorded at 70 days after sowing. After harvesting individual fruit weight $(\mathrm{gm})$, fruit length $(\mathrm{cm})$ and fruit diameter $(\mathrm{cm})$ were recorded.

\subsection{Data analysis}

The mean values of all the recorded parameters were evaluated and analysis of variance was performed using the ' $F$ ' test. The significance of the difference among the treatment means was estimated by Least Significant Different (LSD) test at 5\% level of probability. 
3. Results and Discussion

\subsection{Plant height (cm)}

It is evident from the Figure 1 that, the different treatments exhibited significant effect on plant height at 30, 45 and 60 days after sowing. Plant height was increased gradually with the increase of time. The maximum plant height was found from T1 $(49.96 \mathrm{~cm})$ at 60 DAS, On the other hand, the minimum plant height was found from T4 $(33.09 \mathrm{~cm})$ at 60 DAS. Muqtadir et al., (2019) found that, plant height of okra was significantly higher at 80 days after sowing from mixed of cow dung and inorganic fertilizer compared to other treatment. Kumar et al., (2019) reported that, combined application of organic and chemical fertilizers can increases plant height of okra. Hence, integrated nutrient management maintains organic matter in soil and improving nutrient and structural status of soils which influences vegetative growth and reproductive parameters of okra.

\subsection{Number of leaves per plant}

Number of leaves per okra plant varied significantly among the different treatments of organic and inorganic. The number of leaves per plant was recorded maximum (22.33) at 60 DAT where INM (organic and inorganic) was done and the minimum number of leaves per plant (12.67) was found at 60 DAT from control treatment (Figure 2). Similar result was found by Muqtadir et al., (2019) and they reported that mixed application of cow dung and inorganic fertilizer can improve leaves number of okra plant. According to Anand and Kadam (2016), the number of leaves increased in treatment combinations of neem cake, poultry manure and recommended dose of fertilizers could be attributed to the solubilization effect of plant nutrients and its availability to the plant for its further growth and development.

\subsection{Number of branches per plant}

From the experiment it was observed that number of branches per plant as affected by organic and inorganic fertilizer treatments which are presented in Figure 3. The maximum number of branches per plant 6.33 was recorded on INM (organic and inorganic) at 60 DAT and the control (2.67) with the least. Anand and Kadam (2016) found that, maximum number of branches was observed in the treatment of $60 \% \mathrm{~N}$ through neem cake with $40 \% \mathrm{~N}$ through urea. As the nitrogen is essential for the synthesis of proteins and it might have helped in production of more number of branches. Patil et al. (2004) found the same result in tomato plant. Thus it can be inferred from this result that application of INM (organic and inorganic) significantly affected the number of branches per plant.

\subsection{Days to first flowering}

Considering first flowering date, significant variations were noticed among the all treatments (Figure 4). In T4 treatment the maximum days (45.33 days) required for flower initiation and the minimum days for flowering was found in T1 treatment (39 days). Mishra et al., (2020) reported that, combined effect of chemical fertilizers along with neem oil cake helped to absorb nutrients which was utilized for early initiation of the flowering bud and ultimately develop more flower within a shortest possible period. Therefore, availability of nutrients helps the plant to bear more number of flower and early initiation of the flowering as well as reduces the chances of flower drop resulting in more number of fruits per plant.

\subsection{Number of fruits per plant}

This study revealed that statistical significant differences existed among the treatments for average number of fruits per plant (Figure 5). Data showed the highest fruits number per plant (14.33) was observed from T1 treatment, while the lowest (6) related to control at 70 DAS. Anand and Kadam (2016) showed that, the fruit yield per plot and per hectare has significantly differed with combined application of organic manures and inorganic fertilizers. Among different organic sources of nitrogen, the treatment $60 \% \mathrm{~N}$ through neem cake along with $40 \% \mathrm{~N}$ through urea recorded highest fruit yield per plot and fruit yield per hectare. Similar results regarding the beneficial effect of organic manures and neem cake in particular were also obtained by Shelar $e t$ al., (2011). Prabu et al., (2002) observed that the yield increased by $22.48 \%$ with the application of cow dung and inorganic fertilizers together.

\subsection{Individual fruit weight (gm)}

Regarding of individual fruit weight, variation was found among the practiced treatments (Figure 6). In T1 treatment individual fruit weight is maximum $(24.89 \mathrm{gm})$ and the lowest individual fruit weight $(17.23 \mathrm{gm})$ was observed in T4 treatment at 70 DAS. Mishra et al., (2020) reported that, application of neem oil cake along with chemical fertilizer significantly increased the number of fruits per plant and fruit weight which result in 
increasing yield. Similar findings was obtained by Tripathy and Maity (2009). Islam et al., (2017) also support the result, where the highest yields of tomato was found from the mixed application of organic and inorganic fertilizer. Similar results were found in brinjal by Ullah et al., (2008).

\subsection{Individual fruits length $(\mathrm{cm})$}

Significant difference was observed in case of length of individual fruit (Figure 7). The results showed that, the longest fruit $(15.5 \mathrm{~cm})$ was obtained from combination of inorganic and organic treatment (T1) and the shortest fruit $(7.87 \mathrm{~cm})$ was produced from control treatment at 70 DAS. Thus it can be inferred from this result that integrated nutrient management can improve soil nutrient and structural status which influences vegetative growth and reproductive traits of okra. Muqtadir et al. (2019) reported that mixed application of cow dung and inorganic fertilizer can improve fruits length of okra.

\subsection{Individual fruit diameter $(\mathbf{c m})$}

The application of organic and inorganic fertilizers significantly affected the individual fruit diameter of okra (Figure 8). The highest individual fruit diameter $(1.98 \mathrm{~cm})$ was obtained from the application of T4 treatment, while the lowest fruit diameter $(1.28 \mathrm{~cm})$ was found from the control treatment. Muqtadir et al. (2019) showed that mixed application of cow dung and inorganic fertilizer can improve fruits diameter of okra. Hence, integrated nutrient management have remarkable effect on fruit diameter.

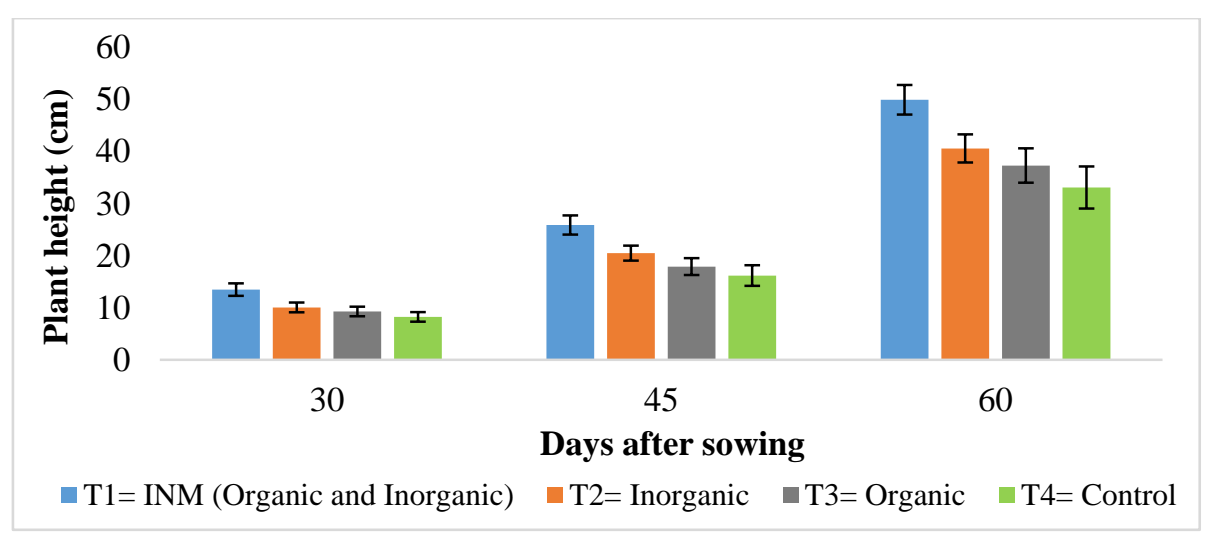

Figure 1. Effect of organic and inorganic fertilizer on plant height of okra at different days after sowing. Vertical bar indicates LSD at 5\% level of significance. (NIM= Integrated Nutrient Management, DAS= Days after sowing).

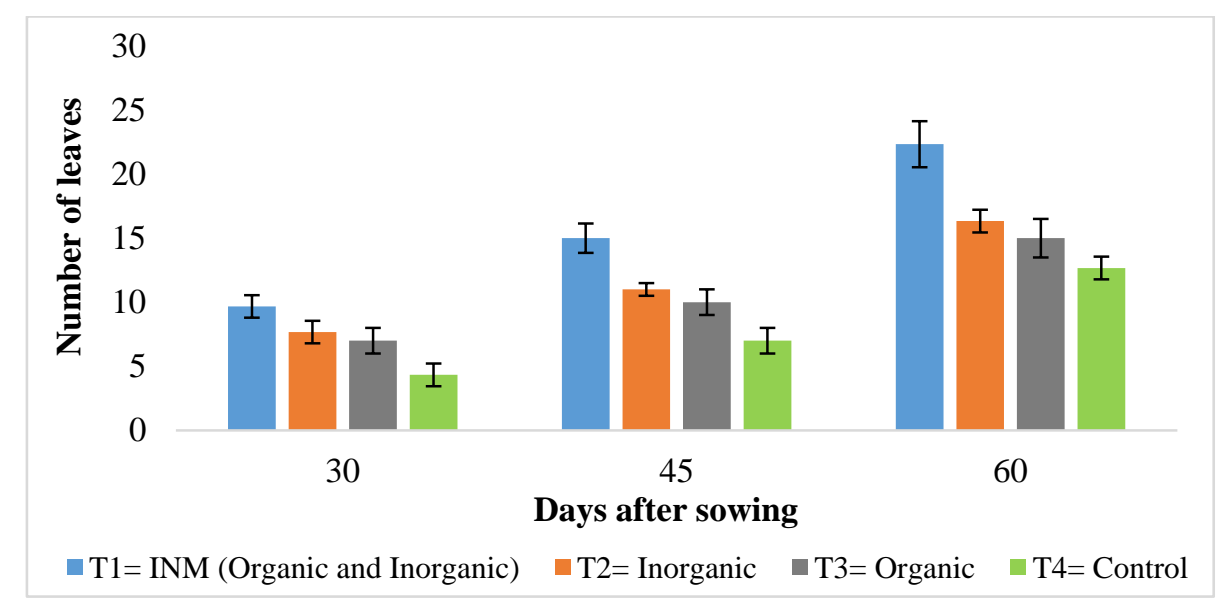

Figure 2. Effect of organic and inorganic fertilizer on number of leaves per plant at different days after sowing. Vertical bar indicates LSD at $5 \%$ level of significance. (NIM= Integrated Nutrient Management, DAS= Days after sowing). 


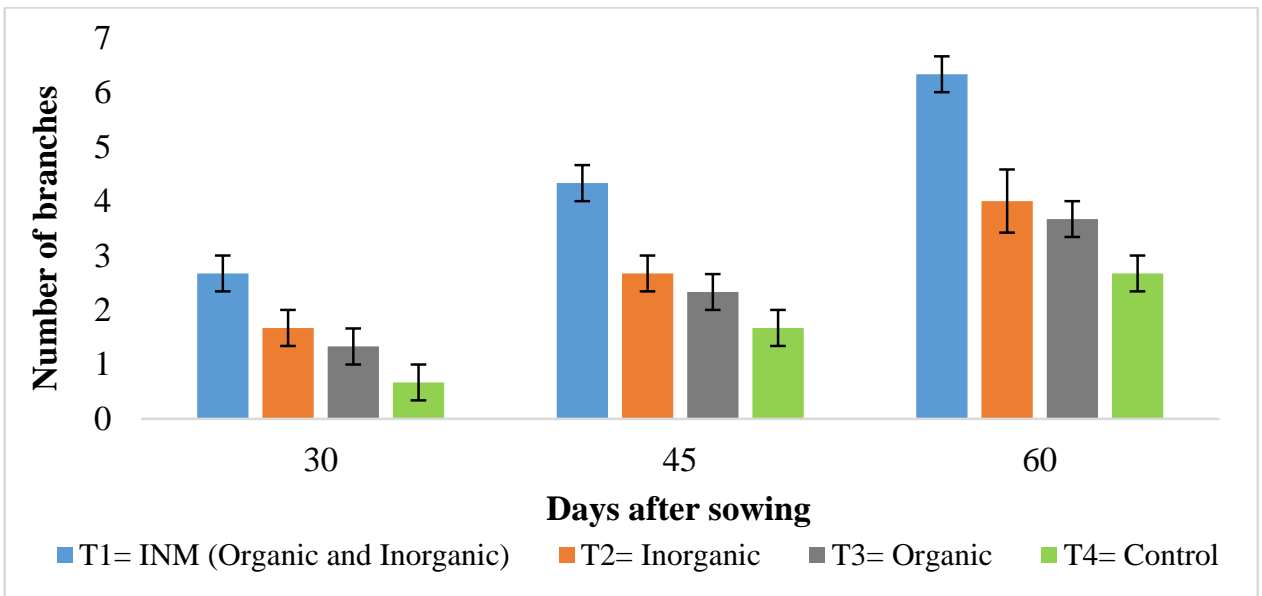

Figure 3. Effect of organic and inorganic fertilizer on number of branches per plant at different days after sowing. Vertical bar indicates LSD at 5\% level of significance. (NIM= Integrated Nutrient Management, DAS= Days after sowing).

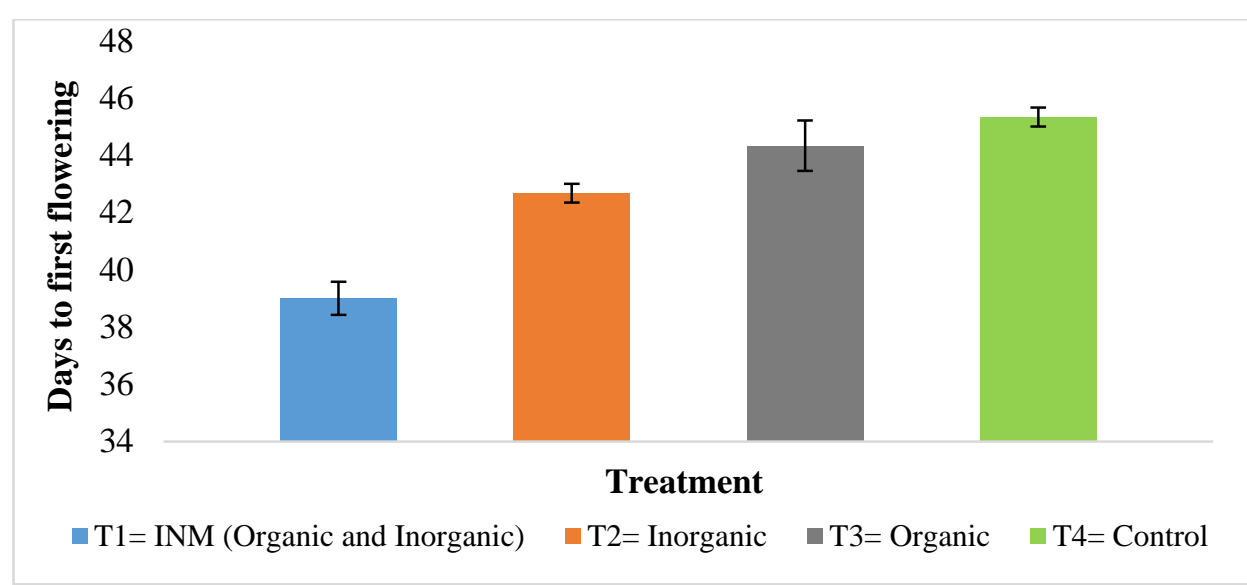

Figure 4. Effect of organic and inorganic fertilizer on days to first flowering of okra. Vertical bar indicates LSD at 5\% level of significance. (NIM= Integrated Nutrient Management, DAS= Days after sowing).

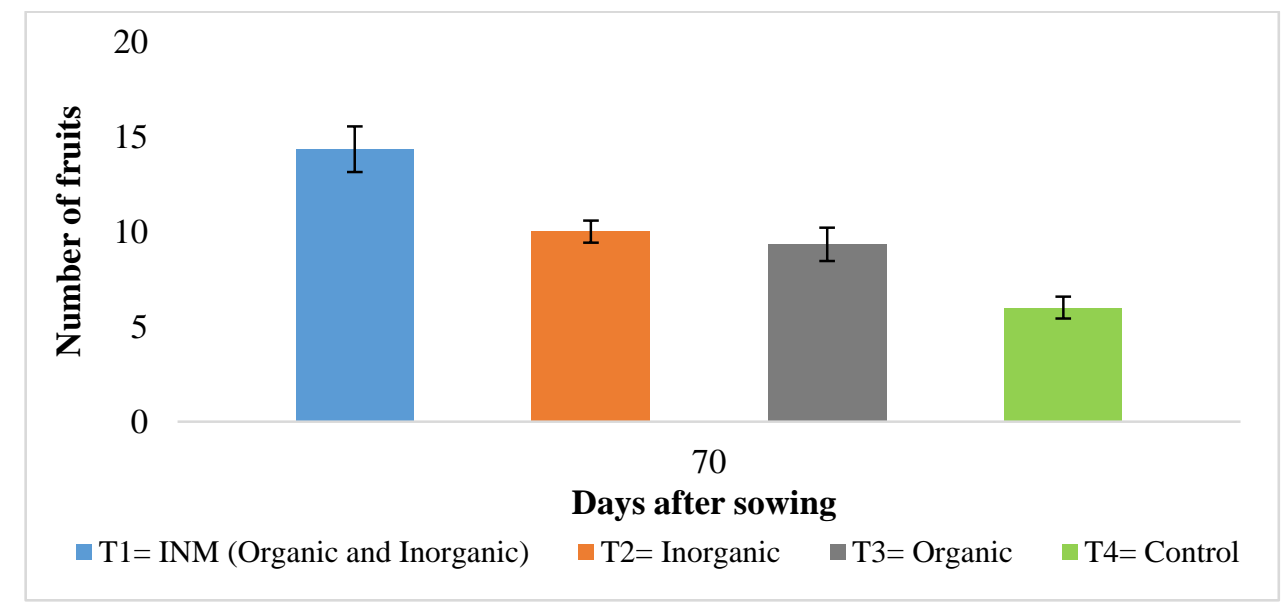

Figure 5. Effect of organic and inorganic fertilizer on number of fruits per plant. Vertical bar indicates LSD at 5\% level of significance. (NIM= Integrated Nutrient Management, DAS= Days after sowing). 


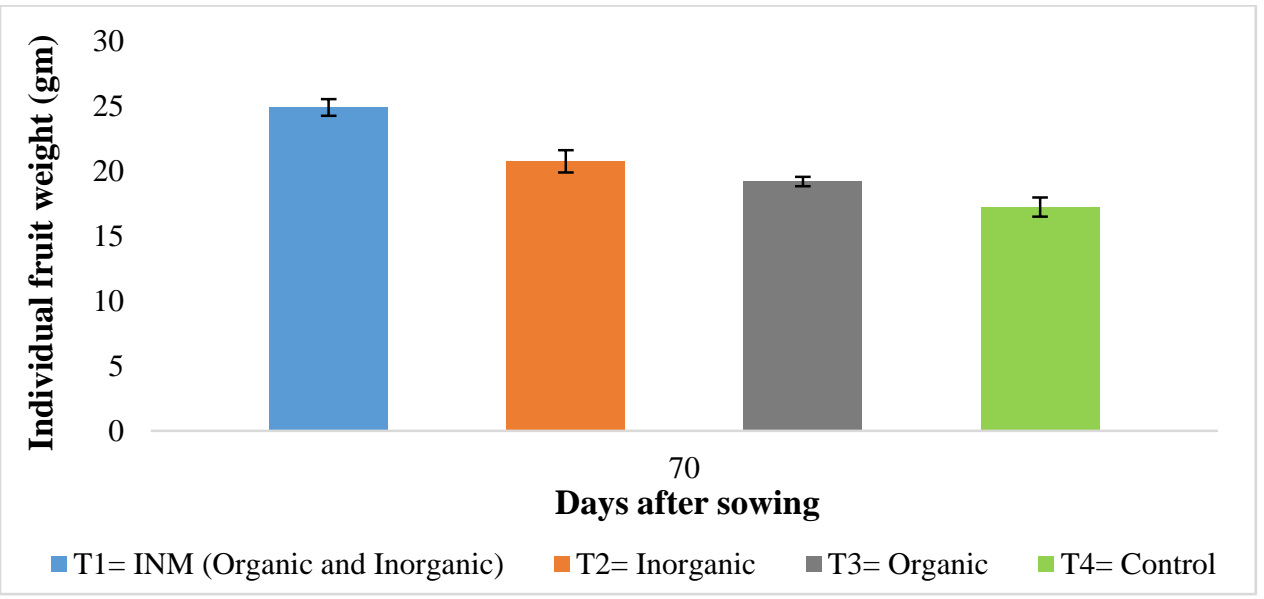

Figure 6. Effect of organic and inorganic fertilizer on individual fruit weight. Vertical bar indicates LSD at $5 \%$ level of significance. (NIM= Integrated Nutrient Management, DAS= Days after sowing).

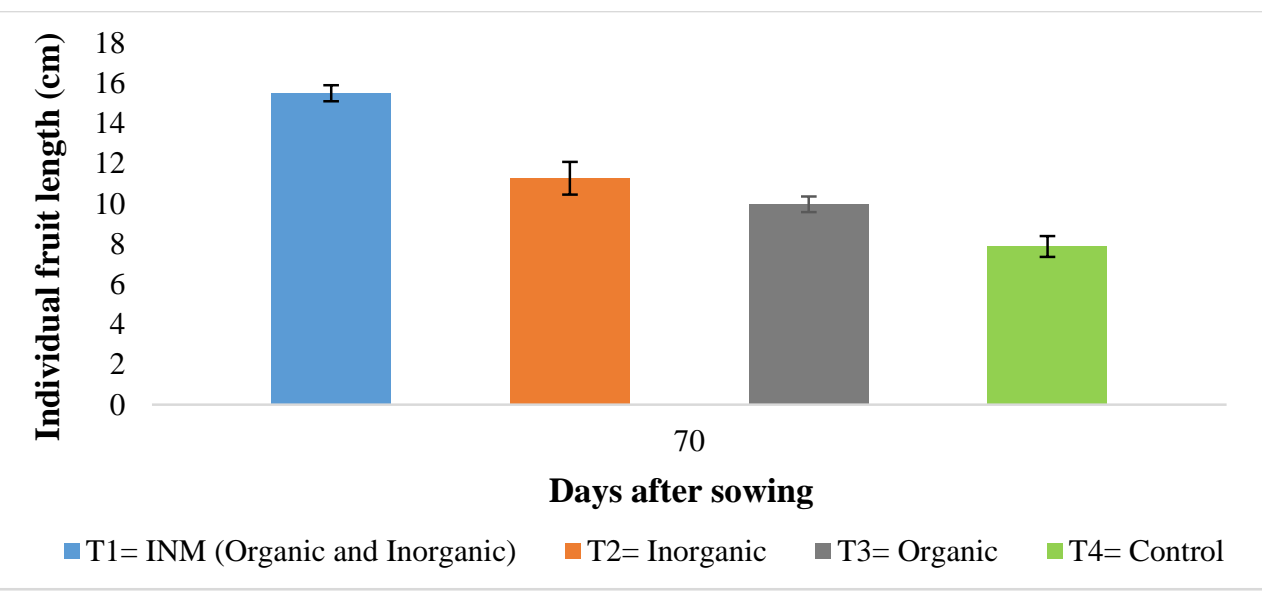

Figure 7. Effect of organic and inorganic fertilizer on individual fruit length of okra. Vertical bar indicates LSD at 5\% level of significance. (NIM= Integrated Nutrient Management, DAS= Days after sowing).

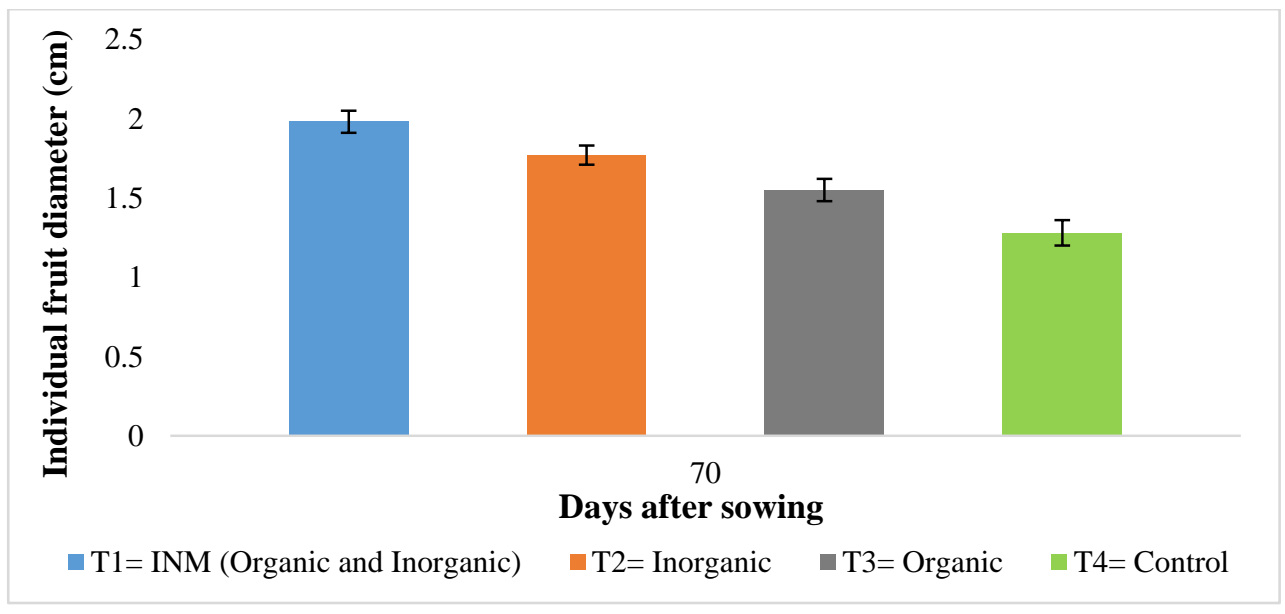

Figure 8. Effect of organic and inorganic fertilizer on individual fruit diameter of okra. Vertical bar indicates LSD at 5\% level of significance. (NIM= Integrated Nutrient Management, DAS= Days after sowing) 


\section{Conclusions}

Integrated nutrient management can furnishes large portion of macro and micro nutrients in soil that influences vegetative and reproductive traits of plant. It also improved the soil health and quality which is important for okra production. So, combined application of organic and inorganic fertilizers are essential for obtaining better growth, higher yield attributes and superior quality of okra fruits. Hence, it can be concluded that, integrated nutrient management has been considered as best treatment for getting higher yield with quality okra production under field condition and further study should be continued in different seasons and different agro ecological zones of Bangladesh for better production.

\section{Acknowledgments}

We would like to thank our family for their financial support towards the successful completion of this study and also thank the other teachers and students of the departments of Agriculture, Noakhali Science and Technology University, Bangladesh.

\section{Conflict of interest}

None to declare.

\section{References}

Anand B and AS Kadam, 2016. Okra crop growth and yield responses to different organic sources of nitrogen. Int. J. Agric. Sci., 8: 2042-2044.

Atijegbe SR, BO Nuga, NE Lale and RN Osayi, 2014. Effect of organic and inorganic fertilizers on Okra (Abelmoschus esculentus L. Moench) production and incidence of insect pests in the humid tropics. Journal of Agriculture and Veterinary Science, 7: 25-30.

Badrie N, 2016. Nutrient profile, bioactive components, and functional properties of okra (Abelmoschus esculentus (L.) Moench). In Fruits, Vegetables, and Herbs Academic Press, pp. 365-409.

Benchasri S, 2012. Okra (Abelmoschus esculentus L. Moench) as a valuable vegetable of the world. Ratarstvo i povrtarstvo, 49: 105-112.

BBS (Bangladesh Bureau of Statistics), 2010. Statistical Year Book, Statistics Division, Ministry of Planning, Government of Peoples Republic of Bangladesh.

Chauhan DVS, 1972. Vegetable Production in India (3rd edition). Ram Prasad and Sons, Agra.

Chowdhury MS, Z Hasan, K Kabir, MS Jahan and MH Kabir, 2014. Response of okra (Abelmoschus esculentus L.) to growth regulators and organic manures. The Agriculturists, 12: 56-63.

FAO (Food and Agriculture Organization), 2006. The state of food and agriculture Food and Agriculture Organization of the United Nations.

FAO/WHO, 2003. Food and Agriculture Organization of the United Nations. Diet, nutrition and the prevention of chronic diseases. Report of a Joint FAO/WHO Expert Consultation. WHO Technical Report Series 916. Geneva, World Health Organization.

Hossain SM, 1992. Status, constrains and strategies of vegetable research. In: Katherine and Eli. L (eds.). Vegetable production and marketing. Proceedings of a national review and planning. Workshop held at BARI, Gazipur, Bangladesh, pp. 31.

Islam MA, S Islam, A Akter, MH Rahman and D Nandwani, 2017. Effect of organic and inorganic fertilizers on soil properties and the growth, yield and quality of tomato in Mymensingh, Bangladesh. Agriculture, 7: 18.

Kumar A, D Tinna and N Gandhi, 2019. Evaluation of biofertilizers and inorganic fertilizers on vegetative growth and yield of okra (Abelomoschus esculentus L. Moench). Journal of Pharmacognosy and Phytochemistry, 4: 91-94.

Mal B, P Mahapatra, S Mohanty and N Mishra, 2013. Growth and yield parameters of okra (Abelmoschus esculentus) influenced by Diazotrophs and chemical fertilizers. J. Crop Weed, 9: 109-112.

Mishra B, GS Sahu, P Tripathy, S Mohanty and B Pradhan, 2020. Impact of organic and inorganic fertilizers on growth, yield, nutrient uptake and soil fertility in okra (Abelmoschus esculentus (L.) Moench) cv. Pusa A-4. The Pharma Innovation Journal, 9: 210-213.

Molik AZ, CV Eluwa, SA Oluwatobi, GY Lakwannum and SK Olorunmaiye, 2016. Effects of Organic and Inorganic Fertilizers on the Yield Components of NH-Ae 47-4 Variety of Okra. Journal of Applied Sciences and Environmental Management, 20: 269-271.

Muqtadir MA, MA Islam, T Haque and A Nahar, 2019. Growth and yield of okra influenced by different types of fertilizers and netting. Progressive Agriculture, 30: 1-9. 
Patil MB, RG Mohammed and PM Ghadge, 2004. Effect of organic and inorganic fertilizers on growth, yield and quality of tomato. Journal of Maharashtra Agricultural Universities, 29: 124-127.

Prabu T, PR Narwadkar and AK Sajindranath, 2002. Integrated nutrient management studies in okra. South Indian Horticulture, 50: 550-553.

Shelar RB, AS Kadam, VK Patil and PB Narsude, 2011. Studies on effect of different sources of nitrogen on growth and yield of okra [Abelmoschus esculentus (L.) Moench]. Int. J. Agric. Sci., 7: 70-73.

Siemonsma JS, 1982. The Cultivation of Okra (Abelmoschus spp), Tropical Fruit Vegetable (with special reference to the Ivory Coast) D.H.O, thesis, Wageningen Agricultural, Wageningen, the Netherlands, pp. 297.

Tripathy P and TK Maity, 2009. Impact of integrated nutrient management on fruit quality and yield of okra hybrids. Crop Research (Hisar), 37: 101-106.

Ullah MS, MS Islam, MA Islam and T Haque, 2008. Effects of organic manures and chemical fertilizers on the yield of brinjal and soil properties. Journal of Bangladesh Agricultural University, 6: 271-276. 